\title{
Interactions between dietary fat type and exogenous enzyme supplementation of broiler diets based on maize, wheat, triticale or barley
}

\author{
S. Dänicke ${ }^{1 *}$, H. Jeroch ${ }^{1}$, O. Simon ${ }^{2}$ and M.R. Bedford ${ }^{3}$ \\ 'Institute of Animal Nutrition and Planned Crop Storage, Agricultural Faculty, \\ Martin-Luther-University IIalle-Wittenberg \\ Emil-Abderhalden-Strasse 26,06108 Halle (Saale), Germany \\ ${ }^{2}$ Institute of Animal Nutrition, Free University of Berlin \\ Brümmerstrasse 34, 14195 Berlin, Germany \\ ${ }^{3}$ Finnfeeds, PO Box 777, Marlborough, Wiltshire, SN8 IXN, UK
}

(Received 26 February 1999; accepted 5 July 1999)

\section{ABSTRACT}

Four growth experiments and a balance study were carried out to examine the effects of different fat types (beef tallow or soyabean oil) in broiler diets based on wheat, triticale, maize or barley in response to feed enzyme supplementation. Performance parameters were recorded over 35 days. Viscosity in the ileal digesta, apparent digestibility of fat and protein at the terminal ileum were measured at day 21 of age. In addition, fat digestibility was measured at the faecal level along with apparent metabolizable energy value $\left(\mathrm{AME}_{\mathrm{N}}\right)$ and apparent net protein utilization $\left(\mathrm{NPU}_{\mathrm{n}}\right)$.

It was found that enzyme addition to all diets improved feed to gain ratio significantly. This was most visible in triticale- and barley-based dicts supplemented with tallow than in the soyabean oilcontaining counterparts until 21 days of age. Effects became smaller or disappeared when the whole fattening period was considered. Significantly better performance of broilers fed soyabean oil compared with tallow-containing diets was observed over the whole fattening period.

Intestinal viscosily was significantly reduced by enzyme addition to all diets. Furthermore, significantly higher intestinal viscosity was found in tallow-fed birds (triticale-, barley- or maize-based diets). Apparent protein digestibility at the terminal ileum was not affected by fat type but was

\footnotetext{
- Corresponding author: Sven Dänicke, Institute of Animal Nutrition, Federal Agricultural Research Centre. Braunschweig (FAL), Bundesallee 50, D-38 116 Braunschweig, Germany
} 
improved by enzyme supplementation in wheat- and barley-based diets. Fat digestibility at both the ileal and faecal levels was significantly higher in birds fed the soyabean oil-containing diets and was significantly improved after enzyme supplementation. The enzyme effect on fat digestibility was more pronounced at the faecal level and was positively correlated to $\mathrm{AME}_{\mathrm{N}}$ and $\mathrm{NPU}_{\mathrm{a}}$.

KEY WORDS: broiler, fat, maize, wheat, triticale, barley, exogenous enzymes

\section{INTRODUCTION}

The supplementation of broiler diets with exogenous enzyme preparations containing hydrolases capable of partial hydrolysis of cereal non-starch-polysaccharides (NSP) is currently a common practice. Enzyme activities of such preparations are matched to the substrate composition of the respective cereals or dicts. Diets containing ryc, wheat or triticale are supplemented with predominantly $x y$ lanase-containing enzyme preparations, whereas predominantly $\beta$-glucanase-containing preparations are added to barley-based diets. The mode of action of added enzymes was recently revicwed by Simon (1998).

However, from a practical point of view, it was shown by Jeroch et al. (1995) that enzyme effects might vary considerably among different experiments. Taking FCR as a criterion (unsupplemented control $=100$ ), ranges in enzyme effects from 94 to $100 \%, 93$ to $100 \%, 92$ to $99 \%$ and 97.5 to $99 \%$ were reported for dicts based on wheat, barley, rye, and triticale, respectively.

It was recognized by several investigators that dietary fat type is one factor contributing to the reported variation in enzyme effects (Smulikowska and Mieczkowska, 1996; Dänicke et al., 1997a,b; Langhout ct al., 1997). Generally, it is shown that enzyme effects are much greater if ryc- or wheat-based dicts contained dietary fat of animal origin instead of plant oils. Improvements in performance were explained by marked increases in fat digestibility. The physiological basis of such effects was reviewed by Smulikowska (1998).

The aim of the present study was to examine whether such interactions might occur in broilers fed unsupplemented or enzyme-supplemented diets based on wheat, triticalc, barley or even maize and containing either beef tallow or soyabean oil.

\section{MATERIAL AND METHODS}

\section{Experimental design}

Each of the four cercals (wheat, triticale, maize, and barley) was combined with either $10 \%$ soyabean oil or $10 \%$ beef tallow and was prepared either with or without an enzyme preparation. Wheat-, triticalc- and maizc-based diets were sup- 
plemented with Avizyme 1300 and the barley-based diets with Avizyme 1100 . The inclusion rate of each enzyme preparation was $1 \mathrm{~g} / \mathrm{kg}$.

Avizyme 1300 (Finnfeeds Int., Marlborough, UK) obtained from Trichoderma longibrachiatum contained $3000 \mathrm{IU} / \mathrm{g}$ xylanase, $40 \mathrm{IU}$ ß-glucanase and $14 \mathrm{IU}$ cellulase activity per g, measured at $\mathrm{pH} 6.0$ on the basis of reducing substance formation. Avizyme 1100 (Finnfecds Int., Marlborough, UK) contained 300 IU $\beta$-glucanase ( $\mathrm{pH} 5.3), 250$ IU xylanase ( $\mathrm{pH} 5.3)$ and 800 IU protease ( $\mathrm{pH} 7.0)$. Furthermore, each dict was supplemented with $0.5 \%$ of $\mathrm{TiO}_{2}$ as an indigestible marker. A total of 16 diets resulted from this experimental design (Table 1 ).

\section{Digestibility measurements}

Birds used in the experiment were male broilers of the Lohmann meat strain grown on a broiler starter diet $\left(230 \mathrm{~g} / \mathrm{kg}\right.$ crude protein, $\left.13.2 \mathrm{MJ} A M E_{\mathrm{N}} / \mathrm{kg}\right)$ in a commercial cage battery until day 10 of age. At this age, cockerels were divided into 16 groups of 20 birds, each group having an cqual mean body weight. Birds were placed into metabolic cages (four per cage) and given experimental diets containing $\mathrm{TiO}_{2}$ as an inert marker. Water and diets were provided ad libitum. Excreta samples were taken per cage ( 5 replications per group) from day 19 to day 21 of age and kept frozen before being further processed. At day 21 of age the broilers were killed by decapitation after cervical dislocation, the intestines were quickly excised and the ileum was ligated and divided into the terminal ileum, corresponding to the length of the cacca, and the proximal ileum, from Meckel's diverticulum to the start of the terminal ileum. Digesta from the proximal and terminal ileum of six or seven birds of each group were pooled separately ( 3 replications per group) and thoroughly mixed. Pooled samples from the proximal ileum were kept on ice before being centrifuged for viscosity measurements. Digesta from the terminal ileum was frozen immediately in liquid nitrogen and kept frozen before being used for determination of digestibility.

\section{Growth experiment}

A total of four growth experiments was carried out. Each of the four experimental diets relating to one cereal type was fed to 90 male broilcr chickens of the Lohmann Meat strain starting on day one of age and ending on day 35 of age within each experiment. The birds were randomly allocated to the experimental groups and divided into nine replications per group with 10 chickens in each. Broilers were kept in three-floor battery cages. The lighting and heating program was adjusted according to the recommendations of the breeder. Feed and water were offered ad libitum. Diets were provided in a pelleted form. Liveweight and feed consumption were recorded on day 21 of age and at the end of the experiment. 
TABLE 1

Composition of the experimental diets, \%

\begin{tabular}{lrrrrrrrr}
\hline Ingredients & \multicolumn{8}{c}{ Cereal type } \\
\cline { 2 - 9 } & \multicolumn{2}{c}{ barley } & \multicolumn{2}{c}{ wheat } & maize & \multicolumn{2}{c}{ triticalc } \\
\hline Barley & 62.95 & 62.95 & - & - & - & - & - & - \\
Wheat & - & - & 56.00 & 56.00 & - & - & - & - \\
Maize & - & - & - & - & 50.00 & 50.00 & - & - \\
Triticale & - & - & - & - & - & - & 57.00 & 57.00 \\
Soya protein isolate & 16.44 & 16.44 & 17.50 & 17.50 & 19.40 & 19.40 & 17.40 & 17.40 \\
DL-methionine & 0.46 & 0.46 & 0.38 & 0.38 & 0.42 & 0.42 & 0.40 & 0.40 \\
L-lysine HCl & 0.24 & 0.24 & 0.24 & 0.24 & 0.18 & 0.18 & 0.20 & 0.20 \\
DL-threoninc & 0.29 & 0.29 & 0.29 & 0.29 & 0.27 & 0.27 & 0.31 & 0.31 \\
Soya oil & 10.00 & - & 10.00 & - & 10.00 & - & 10.00 & - \\
Cellulose & 5.00 & - & 5.00 & 5.00 & 5.00 & 5.00 & 5.00 & 4.89 \\
Tallow & - & 10.00 & - & 10.00 & - & 10.00 & - & 10.00 \\
Maize starch & - & 5.00 & - & 5.00 & - & 5.00 & - & 5.00 \\
Sand & - & - & 5.79 & 0.79 & 9.80 & 4.80 & 4.89 & - \\
Limestone & 0.63 & 0.63 & 0.50 & 0.50 & 0.38 & 0.38 & 0.40 & 0.40 \\
Dicalcium phosphate & 2.71 & 2.71 & 2.95 & 2.95 & 3.20 & 3.20 & 3.05 & 3.05 \\
NaCl & 0.28 & 0.28 & 0.35 & 0.35 & 0.35 & 0.35 & 0.35 & 0.35 \\
Premix & 1.00 & 1.00 & 1.00 & 1.00 & 1.00 & 1.00 & 1.00 & 1.00 \\
Enzyme & $-++^{*}$ & $-+^{2}$ & $-+^{3}$ & $-+^{3}$ & $-+^{3}$ & $-+^{3}$ & $-+^{3}$ & $-+^{3}$
\end{tabular}

Calculated composition, \%
$\mathrm{AME}_{\mathrm{v}}(\mathrm{MJ} / \mathrm{kg})$
13.30
Crude protein
23.00
Lys
1.25
Met+Cys
0.96
Thr
1.00
Trp
0.27
Ca
0.90
$P$
0.70

${ }^{1}$ vitamin-mineral premix provided per $\mathrm{kg}$ of diet:

vitamin A, $12000 \mathrm{IU}$ : vitamin $\mathrm{D}_{3}, 3000 \mathrm{IU}$;, 0.6 ; vitamin $\mathrm{E}, 42 \mathrm{mg}$; vitamin $\mathrm{B}_{1}, 2.1 \mathrm{mg}$; vitamin $\mathrm{B}_{2}, 6.6 \mathrm{mg}$; vitamin $\mathrm{B}_{6}, 4.1 \mathrm{mg}$; vitamin $\mathrm{B}_{12}, 20.7 \mathrm{mg}$; pantothenic acid, $15 \mathrm{mg}$; nicotinic acid, $36 \mathrm{mg}$; folic acid, $1 \mathrm{mg}$; biotin, $102 \mu \mathrm{g}$; choline chloride. $700 \mathrm{mg} ; \mathrm{Fe}, 60 \mathrm{mg}$; Cu, $5 \mathrm{mg} ; \mathrm{Zn}$, $51.4 \mathrm{mg}$ : Mn, $60.8 \mathrm{mg}$; Se, $0.2 \mathrm{mg}$; cthoxyquin, $120 \mathrm{mg}$; Zn-bacitracin, $50 \mathrm{mg}$

2 Avizyme 1100 (Finnfeeds Int.), $1 \mathrm{~g} / \mathrm{kg}$

${ }^{3}$ Avizyme 1300 (Finnfeeds Int.), $1 \mathrm{~g} / \mathrm{kg}$

Carcass characteristics measurements

Onc bird of each replication representing the respective mean liveweight was used for determination of the slaughter yields on day 35 of age. Birds were weighed and killed by cutting the jugular vein after electric stunning. Blecding was fol- 
lowed by scalding in a water bath at $57^{\circ} \mathrm{C}$ for $2 \mathrm{~min}$. Carcasses were then defeathered using a rotary drum picker. The head and feet were removed. Carcasses were cooled for $20 \mathrm{~h}$ at $4^{\circ} \mathrm{C}$ and dissected. Weights of breast skin, total breast meat (without skin), complete right leg, livers and sum of abdominal and visceral fat were individually recorded. The latter parts were excluded in calculation of dressing percentage. All parts were expressed as percentage of liveweight.

\section{Sample preparation}

The pooled and homogenized digesta samples of proximal ileum were centrifuged at $15000 \mathrm{xg}$ for $15 \mathrm{~min}$. The supernatant was then placed on ice until viscosity measurement.

Digesta of terminal ileum and excreta samples were freeze-dricd. The samples (including feed samples) were ground in a freezer mill (Model 6700-230, SPEX CertiPrep Inc., NJ, USA) under liquid nitrogen in order to produce a fine powder and to minimize nutrient losses.

\section{Analysis}

Viscosity of digesta supernatant was measured using a Brookfield viscometer (model DV-II+LV) at $40^{\circ} \mathrm{C}$. Nutrients of diets, digesta and excreta samples were analyzed according to the methods of VDLUFA (Naumann and Basslcr, 1993). Cereal samples were additionally analyzed for starch (polarimetric) and Van Soest-fibre according to the methods of VDLUFA (Naumann and Bassler, 1993). Pentosans of cereals were determined as described by Dusel et al. (1997) and $\beta$-glucans were analyzed by the McCleary-method using an analytical kit (Megazyme, Ircland). Gross encrgy of dicts and freeze-dried excreta was measured using an adiabatic bomb calorimeter (model C 4000, Heitersheim, Germany). $\mathrm{TiO}_{2}$ in feed, digesta and excreta was analyzed according to Brandt and Allam (1987).

\section{Calculations and statistical analysis}

Apparent digestibility at the terminal ilcum and at the faecal level was calculated. Since urinary fat excretion is negligible in broilers, the term digestibility is used for faecal fat as well.

Data were analyzed by two-way ANOVA with fat type and enzyme supplementation as main effects. Significant differences between the means were evaluated by Tukey's HSD test for unequal $n$. All analyses were carried out using the Statistica program for the Windows ${ }^{\mathrm{TM}}$ operating system (StatSoft, Inc., 1994). 


\section{RESULTS}

\section{Chemical composition of cereals}

With respect to cell wall constituents that are the substrates for the added xylanases and $\beta$-glucanases, barley contained both the highest total pentosan and $\beta$-glucan concentrations $(9.4$ and $3.9 \%$, respectively). Wheat and triticale were comparable both in pentosan (6.1 and $6.2 \%$, respectively) and in $\beta$-glucan concentration $(0.6$ and $0.7 \%$, respectively) whereas maize contained approximately the half of the concentration of both constituents as that found in wheat and triticale. The share of soluble pentosans amounted approximately to $22 \%$ in wheat and triticale and $18 \%$ of the total amount in barley and maize. Soluble $\beta$-glucans in wheat, triticale and maize were analytically not detectable. Their share in barley was as high as $48 \%$ of total amount (Table 2 ).

TABLE 2

Chemical composition of the cereals, $\mathrm{g} / \mathrm{kg}$ dry matter

\begin{tabular}{lcccc}
\hline & $\begin{array}{c}\text { Barley } \\
\text { Grete' }\end{array}$ & $\begin{array}{c}\text { Wheat } \\
\text { Mikon' }\end{array}$ & $\begin{array}{c}\text { Maize } \\
\text { 'Mona' }\end{array}$ & $\begin{array}{c}\text { Triticale } \\
\text { no name' }\end{array}$ \\
\hline Starch & 500.3 & 650.8 & 684.9 & 655.8 \\
NDF & 184.8 & 109.8 & 91.2 & 105.1 \\
ADF & 78.2 & 46.5 & 29.3 & 38.5 \\
ADL & 12.1 & 11.0 & 4.8 & 10.4 \\
Hemicellulose & 106.6 & 63.3 & 61.9 & 66.6 \\
Cellulose & 66.1 & 35.5 & 24.5 & 28.1 \\
Total pentosans & 93.6 & 62.0 & 34.0 & 61.3 \\
Soluble pentosans & 16.9 & 13.7 & 6.1 & 13.6 \\
Total B-glucans & 39.1 & 6.1 & 0.9 & 7.1 \\
Soluble B-glucans & 18.9 & $\mathrm{ND}$ & $\mathrm{ND}$ & $\mathrm{ND}$ \\
& & & 107.5 & 121.1 \\
Crude protein $(\mathrm{N} * 6.25)$ & 127.9 & 120.4 & 50.6 & 24.6 \\
Ether extract & 28.1 & 14.8 & & \\
\hline
\end{tabular}

\section{Digestibility measurements}

Apparent digestibility of crude protein (PD), crude fat (FD) and viscosity of the ileal digesta in the proximal ileum is shown in Table 3 . Fat in tallow-containing diets was significantly less digestible than fat in soyabean oil-containing diets $(\mathrm{P}<0.001$, for all cereals). A significant improvement in FD after enzyme supplementation and significant interactions between fat type and enzyme supplementa- 
TABLE 3

Ileal viscosity (Vis, mPas), apparent fat digestibility (FD, \%) and apparent protein digestibility (PD, \%) at the terminal ileum of male broilers in response to cereal, fat type and enzyme supplementation (day 21 of age $)^{1}$

\begin{tabular}{|c|c|c|c|c|c|c|c|c|c|c|c|c|c|}
\hline \multirow{2}{*}{\multicolumn{2}{|c|}{ Enzyme }} & \multicolumn{3}{|c|}{ Maize } & \multicolumn{3}{|c|}{ Wheat } & \multicolumn{3}{|c|}{ Triticale } & \multicolumn{3}{|c|}{ Barley } \\
\hline & & Vis & FD & PD & Vis & FD & PD & Vis & FD & PD & Vis & $\mathrm{FD}$ & $\mathrm{PD}$ \\
\hline Soya oil & - & 3.9 & 92.3 & 91.3 & 8.8 & 87.2 & 85.2 & 17.0 & 91.7 & 87.8 & 13.8 & 86.3 & 83.0 \\
\hline Soya oil & + & 2.9 & 93.1 & 90.9 & 4.7 & 90.0 & 88.7 & 9.3 & 93.0 & 87.9 & 5.0 & 90.2 & 88.3 \\
\hline Tallow & - & 3.2 & 65.2 & 92.0 & 10.2 & 67.4 & 88.3 & 21.9 & 45.3 & 86.2 & 23.8 & 51.3 & 83.8 \\
\hline Tallow & + & 2.4 & 63.4 & 90.6 & 4.6 & 66.7 & 89.2 & 12.4 & 62.8 & 88.4 & 7.6 & 59.4 & 88.7 \\
\hline Pooled SEM & & 0.1 & 2.6 & 0.7 & 1.0 & 1.9 & 0.9 & 1.1 & 2.3 & 1.7 & 1.8 & 3.8 & 0.9 \\
\hline Effects & & \multicolumn{12}{|c|}{ P-values } \\
\hline Fat & & 0.001 & 0.000 & 0.742 & 0.539 & 0.000 & 0.116 & 0.007 & 0.000 & 0.734 & 0.008 & 0.000 & 0.487 \\
\hline Enzyme & & 0.000 & 0.835 & 0.203 & 0.001 & 0.624 & 0.067 & 0.001 & 0.003 & 0.500 & 0.001 & 0.146 & 0.001 \\
\hline Fat x Enzyme & & 0.369 & 0.617 & 0.444 & 0.461 & 0.407 & 0.240 & 0.428 & 0.007 & 0.564 & 0.072 & 0.590 & 0.793 \\
\hline
\end{tabular}

'values represent means of 3 pooled samples per group ( 6 or 7 birds per sample)

${ }^{2} 1 \mathrm{~g} / \mathrm{kg}$ Avizyme 1300 for maize, wheat and triticale based diets, Avizyme 1100 for barley based diet 
tion were observed only for triticale-containing diets $(\mathrm{P}<0.01)$. PD was not affected by fat type in either diet and was significantly improved after enzyme addition in wheat- and barley-containing diets $(\mathrm{P}<0.05$ and $\mathrm{P}<0.001$, respectively). Ileal viscosity decreased significantly after enzyme supplementation to all dicts $(\mathrm{P}<0.001)$. Viscosity was significantly higher in diets containing tallow and triticale or barley $(\mathrm{P}<0.001, \mathrm{P}<0.01$, respectively).

Measurements of fat digestibility at the faecal level (FFD, Table 4) are in general agreement with the digestibility data obtained from the terminal ileum. Fnzyme effect in triticale- and barley-based diets on FFD was significant $(\mathrm{P}<0.05)$. $\mathrm{AME}_{\mathrm{N}}$ values of the diets as well as metabolizability of energy were closely associated with FFD and were significantly higher in soyabcan oil-fed birds $(\mathrm{P}<0.001$ for all diets). Significant enzyme effects for both measures were detected for birds fed triticale- and barley-based diets $(\mathrm{P}<0.001$ and $\mathrm{P}<0.05$, respectively). Moreover, significant interactions between fat type and enzyme supplementation were detected in triticale-fed birds $(\mathrm{P}<0.001)$. Apparent net protein utilization $\left(\mathrm{NPU}_{\mathrm{a}}\right)$ was also significantly influenced by dietary fat type in birds fed triticale $(P<0.01)$, maize $(\mathrm{P}<0.01)$, wheat $(\mathrm{P}<0.001)$ and barley $(\mathrm{P}<0.05)$. Enzyme supplementation significantly improved NPU in triticale- and wheat-fed broilers $(\mathrm{P}<0.05)$.

\section{Growth experiment}

Results of the growth experiments are summarized in Table 5 (day 1 to 21 of age - SFP, day 1 to 35 of age - WFP). Body weight gain (BWG) and feed to gain ratios (FCR) were significantly higher in all soyabean oil-containing diets for SFP only and/or for WFP. Enzyme supplementation significantly improved BWG in diets based on wheat $(\mathrm{P}<0.01$ for SFP), triticale $(\mathrm{P}<0.05$ for WFP) and barley $(\mathrm{P}<0.001$ for SFP, $\mathrm{P}<0.05$ for WFP). FCR was significantly decreased after enzyme addition in diets based on maize $(\mathrm{P}<0.01$ for SFP, $\mathrm{P}<0.05$ for WFP), wheat $(\mathrm{P}<0.05$ for SFP), triticale $(\mathrm{P}<0.01$ for SFP and WFP), and barley $(\mathrm{P}<0.001$ for $\mathrm{SFP})$. BWG and FCR were more significantly increased and decreased, respectively, in tallow-containing diets based on triticale (FCR, $\mathrm{P}<0.01$ for $\mathrm{SFP}, \mathrm{P}<0.05$ for WFP) and barley (BWG, $\mathrm{P}<0.05$ for SFP, FCR, $\mathrm{P}<0.01$ for SFP) as indicated by the significant interactions between fat type and enzyme supplementation.

\section{Carcass characteristics}

Sclected carcass characteristics are summarized in Table 6. The most apparent effects of dietary treatments were observed in carcass fatness as indicated by the sum of abdominal plus visceral fat. Feeding tallow resulted in fatter birds for all cereal types (maize, $\mathrm{P}<0.001$, wheat, $\mathrm{P}<0.05$, triticale and barley, $\mathrm{P}<0.01$ ). In addition, enzyme supplementation increased the fatness of birds fed diets based on 
TABLE 4

$\mathrm{AME}_{\mathrm{N}}$ value of the diets, metabolizability of gross energy $\left(\mathrm{AME}_{\mathrm{N}}: \mathrm{GE}\right)$, apparent net protein utilization $\left(\mathrm{NPU}_{\mathrm{i}}\right.$ ) and faecal fat digestibility (FFD) of broilers in response to cereal, fat type and enzyme supplementation (day 19 to 20 of age) ${ }^{1}$

\begin{tabular}{|c|c|c|c|c|c|c|}
\hline Cereal & Fat & Enzyme $^{2}$ & $\mathrm{AME}_{\mathrm{N}}$ & $\mathrm{AME}_{\mathrm{N}}: \mathrm{GE}$ & $\mathrm{NPU}_{\mathrm{a}}$ & FFD \\
\hline \multirow[t]{9}{*}{ Maize } & Soya oil & - & 13.12 & 71.9 & 63.9 & 91.1 \\
\hline & Soya oil & + & 13.55 & 74.4 & 67.7 & 91.8 \\
\hline & Tallow & - & 12.51 & 68.4 & 61.7 & 65.8 \\
\hline & Tallow & + & 12.50 & 68.6 & 61.1 & 65.5 \\
\hline & Pooled SEM & & 0.12 & 0.01 & 1.6 & 0.6 \\
\hline & Effects & & P-values & & & \\
\hline & Fat & & 0.000 & 0.000 & 0.004 & 0.000 \\
\hline & Enzyme & & 0.101 & 0.064 & 0.258 & 0.646 \\
\hline & Fat $x$ Enzyme & & 0.082 & 0.099 & 0.122 & 0.359 \\
\hline \multirow{9}{*}{ Wheat } & Soya oil & - & 13.04 & 72.4 & 69.8 & 85.4 \\
\hline & Soya oil & + & 13.33 & 74.5 & 74.1 & 89.7 \\
\hline & Tallow & - & 12.21 & 68.2 & 57.8 & 67.6 \\
\hline & Tallow & + & 12.36 & 68.6 & 62.1 & 67.3 \\
\hline & Pooled SEM & & 0.16 & 1.0 & 1.6 & 1.5 \\
\hline & Effects & & P-values & & & \\
\hline & Fat & & 0.000 & 0.000 & 0.000 & 0.000 \\
\hline & Enzyme & & 0.178 & 0.155 & 0.017 & 0.206 \\
\hline & Fat $x$ Enzyme & & 0.675 & 0.356 & 0.970 & 0.142 \\
\hline \multirow[t]{9}{*}{ Triticale } & Soya oil & - & 13.23 & 73.5 & 67.4 & 89.7 \\
\hline & Soya oil & + & 13.58 & 75.1 & 69.5 & 91.2 \\
\hline & Tallow & - & 11.05 & 61.7 & 59.8 & 48.8 \\
\hline & Tallow & + & 12.57 & 69.8 & 66.4 & 64.6 \\
\hline & Pooled SEM & & 0.11 & 1.0 & 1.6 & 1.8 \\
\hline & Effects & & P-values & & & \\
\hline & Fat & & 0.000 & 0.000 & 0.003 & 0.000 \\
\hline & Enzyme & & 0.000 & 0.000 & 0.014 & 0.001 \\
\hline & Fat $x$ Enzyme & & 0.001 & 0.001 & 0.172 & 0.001 \\
\hline \multirow[t]{9}{*}{ Barlcy } & Soya oil & - & 12.66 & 69.9 & 65.2 & 83.0 \\
\hline & Soya oil & + & 12.98 & 71.4 & 67.8 & 88.7 \\
\hline & Tallow & - & 10.80 & 60.0 & 62.2 & 48.4 \\
\hline & Tallow & + & 11.57 & 64.7 & 56.3 & 60.5 \\
\hline & Pooled SEM & & 0.22 & 1.0 & 2.8 & 4.3 \\
\hline & Effects & & P-values & & & \\
\hline & Fat & & 0.000 & 0.000 & 0.017 & 0.000 \\
\hline & Enzyme & & 0.022 & 0.022 & 0.549 & 0.017 \\
\hline & Fat $x$ Enzyme & & 0.321 & 0.202 & 0.142 & 0.970 \\
\hline
\end{tabular}

${ }^{1}$ values represent means of 5 pooled samples per group ( 4 birds per sample)

${ }^{2} 1 \mathrm{~g} / \mathrm{kg}$ Avizyme 1300 for maize, wheat and triticale based diets, Avizyme 1100 for barley based diet 


\begin{tabular}{|c|c|c|c|c|c|c|c|c|c|}
\hline \multicolumn{10}{|c|}{ Body weight gain (BWG, g) and feed to gain ratio (FCR, g/g) of broilers in response to cereal, fat type and enzyme supplementation' } \\
\hline \multirow[t]{2}{*}{ Fat } & \multirow[t]{2}{*}{ Enzyme $^{2}$} & \multicolumn{2}{|c|}{ Maize } & \multicolumn{2}{|c|}{ Wheat } & \multicolumn{2}{|c|}{ Triticale } & \multicolumn{2}{|c|}{ Barley } \\
\hline & & $\mathrm{BWG}$ & FCR & BWG & FCR & BWG & FCR & BWG & FCR \\
\hline \multicolumn{10}{|c|}{ Day 1 to 21 of age } \\
\hline Soya oil & - & 748 & 1.25 & 826 & 1.26 & 749 & 1.35 & 760 & 1.28 \\
\hline Soya oil & + & 742 & 1.24 & 846 & 1.24 & 761 & 1.35 & 797 & 1.26 \\
\hline Tallow & - & 685 & 1.35 & 778 & 1.37 & 673 & 1.48 & 641 & 1.47 \\
\hline Tallow & + & 705 & 1.31 & 824 & 1.29 & 714 & 1.40 & 755 & 1.34 \\
\hline Pooled SEM & & 12 & 0.01 & 15 & 0.024 & 15 & 0.013 & 14 & 0.014 \\
\hline Effects & & \multicolumn{6}{|c|}{ P-values } & & \\
\hline Fat & & 0.001 & 0.000 & 0.007 & 0.001 & 0.001 & 0.000 & 0.000 & 0.000 \\
\hline Enzyme & & 0.568 & 0.002 & 0.010 & 0.019 & 0.077 & 0.006 & 0.000 & 0.000 \\
\hline Fat x Enzyme & & 0.259 & 20.02 & 0.286 & 0.184 & 0.323 & 0.003 & 0.010 & 0.001 \\
\hline \multicolumn{10}{|c|}{ Day 1 to 35 of age } \\
\hline Soya oil & - & 1840 & 1.58 & 1842 & 1.61 & 1758 & 1.66 & 1740 & 1.59 \\
\hline Soya oil & + & 1793 & 1.53 & 1869 & 1.59 & 1820 & 1.65 & 1751 & 1.59 \\
\hline Tallow & - & 1653 & 1.64 & 1759 & 1.70 & 1667 & 1.76 & 1528 & 1.77 \\
\hline Tallow & + & 1688 & 1.62 & 1835 & 1.66 & 1754 & 1.66 & 1719 & 1.69 \\
\hline Pooled SEM & & 32 & 0.016 & 27 & 0.02 & 35 & 0.02 & 49 & 0.026 \\
\hline Effects & & \multicolumn{6}{|c|}{ P-values } & & \\
\hline Fat & & 0.001 & 0.001 & 0.037 & 0.001 & 0.035 & 0.007 & 0.019 & 0.000 \\
\hline Enzyme & & 0.855 & 0.024 & 0.063 & 0.211 & 0.045 & 0.009 & 0.048 & 0.141 \\
\hline Fat $x$ Enzyme & & 0.222 & 0.438 & 0.361 & 0.634 & 0.731 & 0.052 & 0.078 & 0.150 \\
\hline
\end{tabular}

' values represent means of 9 replications per group ( 10 birds per replication)

$21 \mathrm{~g} / \mathrm{kg}$ Avizyme 1300 for maize, wheat and triticale based dicts, Avizyme 1100 for barley based diet 
triticale or barley $(\mathrm{P}<0.01)$. Enzyme supplementation increased breast meat yield and dressing percentage in wheat-fed birds $(\mathrm{P}<0.05)$. Moreover, a significant fat effect on liver weight was observed in these birds $(\mathrm{P}<0.05)$. Other parameters were not significantly influenced by dietary treatments.

\section{DISCUSSION}

The improvement in performance and nutrient digestibility due to exogenous enzyme addition to broiler diets based on wheat, triticale and barley is in agrecment with many literature findings (for review see Jeroch et al., 1995). Similarly, the poorer feeding value of more saturated dictary fats compared with unsaturated fats, for example beef tallow compared with soyabean oil, is also well researched (c.g. Renner and Hill, 1961a, b; Wiseman and Lessire, 1987; Huygebeart et al., 1988; Blanch et al., 1995). In this respect, the presented results are in line with reports on both enzyme and fat effects. Moreover, it was reported by several authors that enzyme supplementation of rye- or wheat-based broiler diets containing animal fats resulted in greater responses than when a plant oil was used (Smulikowska and Mieczkowska, 1996; Dänicke et al., 1997a, b; Langhout et al., 1997). The results of the present study support such findings, although the interactions between fat type and enzyme supplementation were not always significant, it would appear that both performance data and nutrient digestibility in birds fed triticale or barley-based diets were improved to a greater degree if the enzyme preparation was added to the tallow-containing diet. These interactions secmed to be closely associated with the higher intestinal viscosity in birds fed the unsupplemented tallow-containing barley or triticale-based diets. The data suggest that an intestinal viscosity between approximately 2 to $12 \mathrm{mPas}$ (maize- and wheat-based diets, enzyme-supplemented triticale- and barley-based diets) would be of little or negligible consequence, whereas greater than $20 \mathrm{mPas}$ would result in significant deterioration of fat digestibility. However, according to our findings it should be stressed that variation in intestinal and extract viscosity increases progressively when values range between 10 to $20 \mathrm{mPas}$. This is due to the formation of larger aggregates between polysaccharides and/or nutrients and results in relatively high increases in viscosity corresponding to relatively small increases in the concentration of viscosity-contributing substances (Dänicke ct al., 1999a). Such effects could explain, at least in part, the high individual variation of intestinal viscosity within treatments.

The effects of enzyme supplementation of triticale-based diets were shown to be dependent on the pentosan content of triticale. Enzyme effects were smaller when pentosan concentrations in triticale were comparable with wheat and increased with growing pentosan concentrations (Pettersson and Åman, 1988). Flores 
TABLE 6

Carcass characteristics (\% of live weight, day 35 of age) in response to cereal, fat type and enzyme supplementation'

\begin{tabular}{|c|c|c|c|c|c|c|c|}
\hline Cereal & Fat & $\mathrm{me}^{2}$ & Breast & $\begin{array}{c}\text { Thigh } \\
\text { and } \\
\text { drumstick }\end{array}$ & Liver & $\begin{array}{l}\text { Abdominal } \\
\text { and } \\
\text { visceral fat }\end{array}$ & $\begin{array}{c}\text { Dressing } \\
\text { percentage }\end{array}$ \\
\hline \multirow[t]{9}{*}{ Maize } & Soya oil & - & 12.6 & 21.0 & 1.8 & 1.6 & 66.5 \\
\hline & Soya oil & + & 13.0 & 20.8 & 1.7 & 1.4 & 65.6 \\
\hline & Tallow & - & 13.6 & 20.8 & 1.9 & 2.1 & 66.1 \\
\hline & Tallow & + & 12.6 & 20.0 & 1.6 & 2.2 & 65.5 \\
\hline & Pooled SEM & & 0.5 & 0.5 & 0.1 & 0.2 & 0.5 \\
\hline & Effects & & & P-values & & & \\
\hline & Fat & & 0.740 & 0.252 & 0.772 & 0.001 & 0.686 \\
\hline & Enzyme & & 0.615 & 0.432 & 0.088 & 0.752 & 0.152 \\
\hline & Fat $x$ Enzyme & & 0.208 & 0.627 & 0.243 & 0.429 & 0.717 \\
\hline \multirow[t]{9}{*}{ Wheat } & Soya oil & - & 13.8 & 20.6 & 1.6 & 1.9 & 68.0 \\
\hline & Soya oil & + & 16.0 & 22.2 & 1.6 & 1.9 & 69.6 \\
\hline & Tallow & - & 15.0 & 21.6 & 1.9 & 2.9 & 68.5 \\
\hline & Tallow & + & 15.6 & 21.4 & 2.0 & 2.6 & 69.3 \\
\hline & Pooled SEM & & 0.5 & 0.5 & 0.1 & 0.2 & 0.4 \\
\hline & Effects & & & P-values & & & \\
\hline & Fat & & $0.34]$ & 0.789 & 0.036 & 0.001 & 0.817 \\
\hline & Enzyme & & 0.009 & 0.180 & 0.776 & 0.692 & 0.007 \\
\hline & Fat $x$ Enzyme & & 0.102 & 0.062 & 0.711 & 0.558 & 0.393 \\
\hline \multirow[t]{9}{*}{ Triticale } & Soya oil & - & 14.6 & 20.8 & 2.1 & 1.1 & 69.0 \\
\hline & Soya oil & + & 14.0 & 21.2 & 2.1 & 1.8 & 68.8 \\
\hline & Tallow & - & 15.4 & 20.8 & 2.0 & 1.9 & 68.6 \\
\hline & Tallow & + & 14.6 & 21.0 & 2.0 & 2.2 & 69.0 \\
\hline & Pooled SEM & & 0.6 & 0.6 & 0.1 & 0.2 & 0.5 \\
\hline & Effects & & & P-values & & & \\
\hline & Fat & & 0.319 & 0.841 & 0.700 & 0.001 & 0.812 \\
\hline & Enzyme & & 0.225 & 0.622 & 0.898 & 0.009 & 0.812 \\
\hline & Fat $x$ Enzyme & & 0.852 & 0.869 & 0.898 & 0.285 & 0.435 \\
\hline \multirow[t]{9}{*}{ Barley } & Soya oil & - & 15.2 & 21.5 & 2.1 & 1.1 & 70.0 \\
\hline & Soya oil & + & 14.6 & 21.9 & 2.2 & 1.8 & 69.9 \\
\hline & Tallow & - & 15.8 & 21.4 & 2.1 & 2.0 & 69.5 \\
\hline & Tallow & + & 15.1 & 21.8 & 2.1 & 2.3 & 70.5 \\
\hline & Pooled SEM & & 0.6 & 0.5 & 0.1 & 0.2 & 0.6 \\
\hline & Effects & & & P-values & & & \\
\hline & Fat & & 0.332 & 0.805 & 0.604 & 0.001 & 0.943 \\
\hline & Enzyme & & $0.26]$ & 0.542 & 0.753 & 0.006 & 0.476 \\
\hline & Fat $x$ Enzyme & & 0.958 & 0.990 & 0.983 & 0.291 & 0.358 \\
\hline
\end{tabular}

values represent means of 9 birds per group

${ }^{2} 1 \mathrm{~g} / \mathrm{kg}$ Avizyme 1300 for maize, wheat and triticale based dicts, Avizyme 1100 for barley based dict 
et al. (1994) reported improvement in performance ranging between 11 and $23 \%$ in broilers from day 10 to 24 of age with enzyme supplementation when given diets containing $60 \%$ triticale (different varieties) and $3 \%$ tallow. The water-soluble pentosan content ranged between 2.4 and $2.7 \%$ and did not correlate with triticale feeding value. However, the varieties differed significantly with respect to performance. The authors concluded that factors other than soluble pentosans must be responsible for differences in feeding value of triticale. Scholtyssek and Knorr (1987) measured fat digestibility in broilers fed diets containing either $30 \%$ triticale or $30 \%$ rye, $5 \%$ soyabean oil and a multi-enzyme preparation. The improvement in fat digestibility amounted to 3.2 and $1.1 \%$ in triticale- and rye-containing diets, respectively, which supports the findings of the present study where changes in fat digestibility due to enzyme supplementation in soyabean oil-containing diets were only marginal.

In the present cxperiment, both chemical composition of wheat and triticale and improvement in performance of broilers after enzyme addition were comparable. For both cereals, there was a trend towards greater enzyme effects in groups fed the tallow-containing diets, with this effect on FCR reaching significance in triticale-fed birds. Improvement in BWG and FCR until day 21 of age amounted to 0 to $2 \%$ and 5 to $6 \%$ in soyabean oil- and tallow-fed birds, respectively. These effects were smaller when the whole fattening period was considered. A direct relationship between fat digestibility and performance was found for triticaleand barley-fed birds. The marked improvement in fat digestibility in tallow-supplemented triticalc- or barley-fed birds on enzyme supplementation coincided with an improvement in FCR (day 1 to 21 of age) of 6 and $8 \%$, respectively. The $5 \%$ enzyme-related improvement in FCR in tallow- and wheat-fed birds seemed not to be related to fat digestibility but more to precaecal protein digestibility and NPU

Intestinal viscosity in birds fed the unsupplemented wheat-tallow diet was only half that of their triticale-fed counterparts. Intestinal viscosity is considered to influence fat digestibility markedly, as discussed in more detail by Dänicke et al. (1997b) and Smulikowska (1998). It would appear from the present results that a marked reduction in fat digestibility might be expected at an intestinal viscosity of approximately $20 \mathrm{mPas}$. This is also supported by the approximately 8 and $12 \%$ lower FD and FFD, respectively, in broilers fed the unsupplemented barley-tallow diet compared with their $\beta$-glucanase-supplemented counterparts. Rotter et al. (1990) measured the $\mathrm{AME}_{\mathrm{N}}$ of a hull-less barley in the presence of either $4 \%$ maize oil or $4 \%$ tallow and found an improvement after enzyme supplementation of 20 and $33 \%$, respectively, which supports the existence of interactions between fat type and enzyme supplementation. At the same time, FCR decreased by 9 and $11 \%$, respectively. Hulled barley was used in the present study, therefore, the higher total fibre content might also be involved in modulating its nutritive valuc. This 
is supported by Villamide et al. (1997) who estimates that $55 \%$ of the $\mathrm{AME}_{\mathrm{N}}$ value of cnzyme-supplemented barley cultivars is accounted for by crude fibre content. Therefore, the feeding value of barley for broilers not only depends on the soluble $\beta$-glucan content and intestinal viscosity, but on elimination of this problem through enzyme use; crude fibre or total cell wall content then becomes a very important factor. Enzyme supplementation of maize-based diets did not improve nutrient digestibility, $\mathrm{AME}_{\mathrm{N}}$ or $\mathrm{NPU}$. Despite this, xylanase addition was effective in reducing intestinal viscosity. As discussed above, the low intestinal viscosity in maize-fed birds is accompanied by a relatively small standard error whereby treatment differences became significant. However, the absolute level of viscosity and the enzyme effects seemed to be without physiological significance in terms of cxamined nutrient digestibility. On the other hand, FCR was significantly reduced due to enzyme supplementation in maize-fed birds irrespective of fat typc, which can not be explained by the measured digestibility data. Digestibility of starch as the major energy yiclding compound in maize could be improved by enzyme supplementation. It should be noted, however, that the enzyme preparation used for maize diets is matched to wheat- or wheat-and-rye-based diets which contain much higher amounts of pentosans than maize (Table 2). An cnzyme preparation which is better matched to maize or maize-soyabean-based diets (amylase, protease and xylanase activities) might produce more consistent effects as shown by Pack et al. (1997) where a 2 to $5 \%$ improvement in ileal energy digestibility was reported for different diets based on maize.

The most pronounced effects of the dietary treatments on carcass characteristics were observed for the abdominal plus visceral fat content. Feeding tallow resulted in significantly fatter broilers when compared with soyabean oil. It has been shown by several authors (De Groote et al., 1971; Fuller and Rendon, 1979; Brue and Latshaw, 1985; Dänicke et al., 1999b) that feeding tallow or fats of animal origin containing high ratios of saturated to unsaturated fatty acids results in a higher caloric efficiency, i.e. a higher proportion of net encrgy to metabolizable cnergy, than feeding plant oils. In some of these studies, the birds fed the tallowbased diets were in fact fatter (De Groote et al., 1971; Pinchasov and Nir, 1992). It was hypothesized by Pinchasov and Nir (1992) that dietary polyunsaturated fatty acids, which are more abundant in soyabean oil than in tallow, modulate the 9-desaturase complex which causes a reduction in synthesis of oleic acid and a decrease in lipogenesis.

Birds fed the barley or triticalc dicts were fatter on enzyme supplementation. Fatness increased both in soyabean oil- and in tallow-fed birds, which may be related to improved fat digestibility suggesting a higher energy availability for fat deposition. Similar trends were reported by Dänicke et al. $(1999 \mathrm{c})$ who found the degrec of fatness of broilers directly related to dietary pentosan concentration and enzyme supplementation. 


\section{CONCLUSIONS}

Enzyme supplementation of broiler diets based on wheat, triticale, barley and, to a lesser extent, maize is beneficial in terms of improvement of performance, especially during the first wecks of life, and more pronounced if beef tallow is used instead of soyabean oil at $10 \%$ dietary inclusion.

\section{EFERENCES}

Blanch A., Barroeta A.C., Baucells M.D., Puchal F., 1995. The nutritive value of dietary fats in relation to their chemical composition. Apparent fat availability and metabolizable energy in two-week-old chicks. Poultry Sci., 74, 1335-1340

Brandt M., Allam S.M., 1987. Analytik von $\mathrm{TiO}_{2}$ im Darminhalt und Kot nach Kjeldahlaufschluss. Arch. Anim. Nutr, 37, 453-454

Brue R.N., Latshaw J.D., 1985. Energy utilization by the broiler chicken as affected by various fats and fat levels. Poultry Sci., 64, 2119-2130

Dänicke S., Franke E., Strobel E., Jeroch H., Simon O., 1999b. Effects of dietary fat lype and xylanase supplementation in rye containing broiler diets on energy metabolism in male broilers. J. Anim. Physiol. Anim. Nutr., (in press)

Dänicke S., Jeroch H., Dusel G., Simon O., Bedford M., 1999c. Eflects of fat type, pentosan level and xylanase supplementation on performance and carcass characteristics of male broilers. Arch. Geflügelk. (in press)

Dänicke, S., Simon O., Jeroch H., 1999a. Effects of supplementation of xylanase or B-glucanase containing enzyme preparations to either rye- or barley-based broiler diets on performance and nutrient digestibility. Arch. Geflügelk, (in press)

Dänicke S., Simon O., Jeroch H.. Bedford M.. 1997a. Interactions between dietary fat type and xylanase supplementation when rye-based diets are fed to broiler chickens. 1. Physico-chemical chyme features. Brit. Poult. Sci., 38, 537-545

Danicke S., Simon O.. Jeroch H., Bedford M., 1997b. Interactions between dietary fat type and xylanase supplementation when ryc-based diets are fed to broiler chickens. 2. Performance, nutrient digestibility and the fat-soluble vitamin status of livers. Brit. Poultry Sci.. 38, 546-556

De Groote G., Reyntens N., Amich-Gali J., 1971. Fat studies. 2. The metabolic efliciency of energy utilization of glucose, soybean oil and different animal fats by growing chicks. Poultry Sci. 50 , 808-819

Dusel G., Kluge H., Gläser K., Simon O., Hartmann G., Von Lengerken J., Jeroch H., 1997. An investigation into the variabilty of extract viscosity of wheat - relationship with the content of non-starch-polysaccharide fractions and metabolisable energy for broiler chickens. Arch. Anim. Nutr. 50, 121-135

Flores M.P., Castanon J.I.R.. McN'ab J.M., 1994. Effect of enzyme supplementation of wheat and triticale based diets for broilers. Anim. Fecd Sci. Technol., 49, 237-243

Fuller H.L., Rendon M., 1979. Energetic elficiency of corn oil and poultry fat at different levels in broiler diets. Poultry Sci. 58, 1234-1238

Huyghebaen G.. de Munter G., de Groote G., 1988. The metabolisable energy (AMEn) of fats for broilers in relation to their chemical composition. Anim. Feed Sci. Technol., 20, 45-58

Jeroch H., Dänicke S., Brufau J., 1995. The influence of enzyme preparations on the nutritional value of ceral for poultry. A review. J. Anim. Feed Sci., 4, 263-285 
Langhout D.J., Schutte J.B., Geerse C., Kies A.K., De Jong J., Verstegen M.W.A., 1997. Effects on chick performance and nutrient digestibility of an endo-xylanase added to a wheat- and ryc based diet in relation to fat source. Brit. Poultry. Sci., 38, 557-563

Naumann, C., Bassler, R., 1993. Die chemische Untersuchung von Futtermitteln. VDLUFA-Verlag, Darmstadt (Germany)

Pack M.R., Bedford M.R., Coon C., Rostagno H.S., 1997. Effects of feed enzymes on ileal digestibility of energy and protein in corn-soybean diets fed to broilers. Proccedings of Il th European Symposium on Poultry Nutrition, Faaborg (Denmark), pp. 502-504

Pettersson D., Aman P., 1988. Effect of enzyme supplementation of diets based on wheat, ryc or triticale on their productive value for broiler chickens. Anim. Feed Sci. Technol., 20, 313-324

Pinchasov Y., Nir l., 1992. Effect of dietary polyunsaturated fatty acid concentration on performance, fat deposition, and carcass fatty acid composition in broiler chickens. Poultry Sci., 71. $1504-1512$

Renner R., Hill F.W., 1961a. Utilization of fatty acids by the chicken. J. Nutr., 74, 259-264

Renner R., Hitl F.W., 1961b. Factors affecting the absorbability of saturated fatty acids in the chick. J. Nutr., 74, 254-258

Rotter B.A., Friesen O.D., Guenter W., Marquardt R.R., 1990. Influence of enzyme supplementation on the bioavailable energy of barley. Poultry Sci., 69, 1174-1181

Scholtyssek S., Knorr R., 1987. Die Wirkung eines cellulotytischen Enzympräparates bei Verfütterung von Triticale- und Roggenrationen an Broiler. Arch. Geflügelk., 51, 10-15

Simon O., 1998. The mode of action of NSP hydrolysing enzymes in the gastrointestinal tract. J. Anim. Feed Sci., 7, Suppl. 1, 115-123

Smulikowska S., 1998. Relationship between the stage of digestive tract development in chicks and the effect of viscosity reducing enzymes on fat digestion. J. Anim. Feed Sci., 7, Suppl. 1, $125-134$

Smulikowska S., Mieczkowska A., 1996. Etfect of rye level, fat source and enzyme supplementation on fat utilization, diet metabolizable energy, intestinal viscosity and performance of broiler chickens. J. Anim. Fecd Sci., 5, 379-393

StatSoft, Inc., (1994): . Statistica for the Windows ${ }^{\mathrm{TM}}$ Operating System. Tulsa OK, USA

Villamide M.J., Fuente J.M., Perez de Ayala P., Flores A., 1997. Energy evaluation of eight barley cultivars for pouitry: effect of dietary enzyme addition. Poultry Sci., 76, 834-840

Wiseman J., Lessire M., 1987. Interactions between fats of differing chemical content: apparent metabolisable energy values and apparent fat availability. Brit. Poultry Sci., 28, 663-676

\section{STRESZCZENIE}

Współzależność pomiędzy rodzajem tłuszczu i dodatkiem enzymów egzogennych do diet, zawierających kukurydzę, pszenicę, triticale lub jęczmien, w żywieniu brojlerów

Przeprowadzono cztery doświadezenia wzrostowe i jedno bilansowe w celu zbadania wpływu różnego rodzaju tłuszczu (łój wołowy lub olej sojowy) oraz dodatku enzymów do dict zawicrających pszenicę, triticale, kukurydzę lub jęczmień. Doświadczenia wzrostowe prowadzono przez 35 dni. W doświadczeniu bilansowym u kurcząt w wieku 21 dni oznaczono lepkość tréści jelita biodrowego oraz pozorną strawność thuszczu i białka w koncowej części jelita biodrowego. 
Oznaczono takżc calkowitą strawność tłuszczu, zawartość encrgii metabolicznej (AME) oraz pozorne wykorzystanie białka netto (NPU ${ }_{\mathrm{a}}$ ).

Dodatek enzymów do wszystkich diet poprawiał istotnic wykorzystanic paszy, szczególnie w przypadku diet zawierających triticale $\mathrm{i}$ jęczmien $\mathrm{i}$ uzupełnionych łojem $w$ porównaniu z dietami uzupełnionymi olejem sojowym. Efekt dodatku enzymów zmniejszał się lub nie występował, gdy uwzględniano cały okres tuczu. Lepsze wyniki produkcyjne w całym okresie tuczu uzyskano u kurcząt otrzymujących diety uzupełnione olejem niż łojem.

Lepkość treści jelitowej istotnie zmniejszała się pod wpiywem dodatku enzymów do wszystkich diet; lepkość była istotnic wiçksza u kurcząt otrzymujących dicty z łojem (z triticale, jęczmienicm lub kukurydza). Pozorna strawność oznaczana w jelicie biodrowym nie zależała od rodzaju tłuszczu, natomiast zwiększała się pod wpływem dodatku enzymów do diet 7 pszenicą i jęczmienicm. Całkowita i jelitowa strawność tłuszczu była istotnie większa u kurcząt otrzymujących dietę $\mathrm{z}$ dodatkiem oleju $\mathrm{i}$ istotnie wzrastała pod wpływem dodatku enzymów. Wpływ enzymów na całkowitą strawność tłuszczu zaznaczył się wyraźniej niż na jelitową, i był dodatnio skorelowany z. $\mathrm{AME}_{\mathrm{N}}$ i NPU $_{\mathrm{i}}$. 